\title{
Role of Leader-Member Exchange and Impression Management in Employee Performance at Hotels
}

\author{
Mohamed Agina* Mohamed Aboutaleb Mohammed** Abdelmonem Omar** \\ *Higher institute for specific studies, Heliopolis, Cairo. \\ **Faculty of tourism and hotels, University of Sadat City
}

\begin{abstract}
The objective of current research is to determine the role of leader-member exchange and impression management in employee performance at hotels. It aims, on the one hand to identify the relationship between different impression management tactics and employee performance and on the other hand between leader-member exchange and employee performance. This research is based on survey methodology. A convenience sample of 362 employees representing 20 five star hotels Located in Cairo were chosen for investigation. Results of this study revealed that there is a significant difference between leader member exchange and employee performance. In addition, leader-member exchange was found to have a significant relationship with impression management.

Five impression management behaviors were chosen in the research to investigate its effects on employee performance namely; self-promotion, ingratiation, exemplification, intimidation, and supplication. The research findings also revealed that there is no significant difference between impression management and employees performance.
\end{abstract}

Key words: Impression Management, Leader Member Exchange, Employee Performance.

\section{Introduction}

As employees confront scarce resources, increasingly competitive environment and an unstable economy, they must find ways to increase their perceived value to the organization. To do this, an individual must engage in political behaviors with the aim of positioning himself as a powerful and crucial person. Impression management is a specific type of political behavior intended to persuade an audience to view someone in a particular way and to create and maintain desired images of himself (Schlenker, 1982). People are all motivated to manage impressions and frequently do so to achieve important outcomes such as job satisfaction, supervisor satisfaction, decreasing intent to turnover, raising performance appraisal, and reducing job stress. This study focuses on one of these outcomes which are employee's performance.

Impression management has become an important focus within many several modern organizations. Supervisors are interested to know the different impression management tactics to judge whether subordinate's attempts are 
sincere and built on safe ground of accomplishments and good work, or insincere and purely based on self-interest. These behaviors are clearly highlighted with the presence of LMX in organizations. LMX theory holds that leaders develop unique relationships with their various subordinates These relations range from low to high quality, depending on the degree of the presence of each of the four LMX dimensions, which are: 1) affect, 2) loyalty, 3) contribution, and 4) professional respect. LMX results in exchange of valuable resources for both sides, such as better job assignments and more freedom at work (for the member), and increased effort by the subordinate to achieve extra tasks and showing greater loyalty (for the leader).

This Research goes more in-depth into the different forms of impression management behaviors, together with the leader-member exchange theory and dimensions, and their possible effects on employee's performance. There is a scarcity of studies which attempted to understand the relationship between impression management behaviors and leader-member exchange. Understanding these two concepts well can help much to enhance a more stable work environment.

\section{Literature Review}

\subsection{Development of LMX theory}

The LMX theory begins as another leadership theory but it considers different from other leadership theory. Consequently, to see how LMX theory works, early studies have indicated how it can be clarified by the concepts of two theories; the role theory and the social exchange theory (Graen, 1976).

\subsubsection{The Role theory}

Within any relationship, there are certain roles that each person has. That is, there are expectations about who is to do what in a relationship (Katz \& Kahn, 1966). From the perspective of LMX theory, the roles that supervisors and subordinates take on in a high-quality relationship mature and stabilize over time. The relationship goes through stages of role-development before it is fully established (Graen \& Scandura,1987).

\subsubsection{The Social Exchange Theory}

High-quality relationship is based on terms of reciprocity (Gouldner, 1960). That is when one gives something, he or she expects something in return. This theory differs from purely economic exchanges because economic exchanges are, in most cases, one time transactions (Blau,1964). Social exchanges are based on the assumption that the individuals involved in the transaction are going to exchange assets, either tangible or intangible, in the near future, and on multiple occasions (Truckenbrodt, 2000). Furthermore, it is assumed that with social exchange relationships, reciprocation will be of a constant and continuous nature (Blau, 1964). 
As indicated by Graen and Uhl-Bien (1995) leadership can be categorized in three stages: (a) the more odd stage, (b) the associate stage, and (c) the full grown stage. As indicated by them, in the "more interesting stage", the nature of the relationship is powerless and the leader is principally roused without anyone else's input intrigue as opposed to gathering interest. In any case, the individuals will agree to the leaders as he has position power and control rewards. This is trailed by the "colleague stage" where we start to see enhanced profession arranged social exchanges.

This generally begins with either side offering to share more assets or individual or business-related data. This is likewise a testing ground to check whether the individual will get more difficulties and the leader will offer more difficulties. At long last the 'mature stage' where trust and common appreciation created in the aforementioned stage will become further. The leader and individual will start to depend on each other in profitable ways and their will concern be for the better of the group and association as opposed to self-interest (Graen and Uhl-Bien,1995).

\subsection{Directionality of impression management}

\subsubsection{Protective and acquisitive tactics}

Concern on explain dichotomies that exist in relation to the directionality of self-presentation. First, protective versus acquisitive, the latter are actions seek the social approval or similarly to "enhance undefined favored treatment in unknown future circumstances" (Arkin1981). Therefore, the underlying basis of acquisitive presentation "characteristically involves impressing others favorably whenever and wherever possible". Conversely protective behaviors aim to carefully avoid "social disapproval" that would result in "specific and rather immediate loss or punishment” (Arkin and Sheppard,1990).

\subsubsection{Assertive and defensive tactics}

Tedeschi (1985)discuss assertive and defensive impression management. Assertive presentation is defined as actions aimed at projecting a particular image. It is "broadly conceived to include acquisitive self-presentation" (Arkin and Sheppard 1990) and hence is largely equivalent to Arkin's (1981)'s notion above.

Roth et al., (1988) present two distinct tactics for creating the desired impression; the 'attributive tactic' which involves communicating the possession of positive characteristics (wealthy, intelligent and honorable) and the 'repudiative tactic' which is the denial of possession of negative characteristics (poor, unintelligent and dishonorable). 
The main contribution of Schutz (1998) is to categorize impression management strategies, not just according to direction (as do the dichotomies above), but also according to "how actively the person engages" in these tactics, his taxonomy categorizes self-presentational acts as part of an assertive, offensive, defensive or protective style Assertive self-presentation involves 'trying to look good by presenting a favorable image. This involves active but not aggressive endeavors by individuals to give the impression that they possess certain characteristics being good at maths though not necessarily the 'best' in the class.

Techniques for this may include verbal claims to membership or symbolic cues, wearing a group emblem. Assertive presentation simply shows an individual in a desired light, whereas second category offensive does the same, however through the domination or degradation of others. Hence, individuals 'try to look good by making others look bad, thus it is unsurprising this strategy is known as "aggressive" (Schutz, 1998).

\subsubsection{Protective and defensive tactics}

Protective presentation is aimed not at creating a good impression but at avoiding a bad one. Thus, actions are not made to display desired identities but to circumvent those which are undesirable. This is a more passive strategy when compared to defensive presentation, as people avoid, rather than correct, undesired images. This typically involves sidestepping situations that could be humiliating or embarrassing, so forgoing more risky methods that might affect impressions positively (Leary and Kowalski, 1995).

People may also endeavor to limit difficult interactions by simply behaving pleasantly when any interaction is required (Arkin, 1981). The following behavioral strategies are categorized as protective presentation. First, avoiding public attention can protect presentation as it minimizes the chance of evaluation (Leary and Kowalski, 1995; Schütz ,1998). Second, minimizing self-disclosure, hence the less an individual says about themselves, the less they can be criticized (Schlenker and Leary ,1985). People may describe themselves modestly or be self-deprecating (Arkin, 1981; Schlenker and Leary, 1985). Self-handicapping strategies may also be used, explaining that one may not perform well due to illness (Baumgardner and Arkin, 1987). Lastly, people may choose to show themselves as passive, friendly or agreeable as a low risk strategy in order to reduced criticism (Schlenker and Leary, 1985; Schutz et al., 1997).

Different to these rather passive protective strategies, defensive strategies are more involved and adopted when there is a belief that identity has become threatened or damaged (Tedeschi ,1985). For now, it will suffice to say that they are circumstances in which events, future or present, threaten the image of an individual (Schlenker, 1980; Leary and Kowalski, 1995). 


\subsection{Performance Appraisal in Theory: Expected Benefits}

Performance appraisal has been recognized as an important management tool for measuring employee job performance, clarifying personnel decisions such as promotion, demotion, transfer, or retention, and allocating financial rewards; as well as helping develop employee capacity through feedback or identifying their training needs (McGregor 1972; Decotiis and Petit 1978; Huber 1983; Mohrman et al. 1989; Lacho et al. 1991; Murphy and Cleveland 1991; Longenecker and Nykodym 1996; Gabris and Ihrke 2001; Roberts and Pavlak 1996; Oh and Lewis 2009).

Similarly, Mohrman et al., (1989) concluded that PA serves as an important communication tool between an organization and its employees that aids aligning employee performance goals with organizational goals. They also emphasized that if PA is properly used, it can contribute to boosting employee motivation and their productivity. Lacho et al., (1991) highlighted the usefulness of the PA management tool in terms of making an organization more efficient by helping justify large personnel expenditures given that the added expense is one of the major costs for the government, managers consistently contend they are unwilling to abandon PA because they view them as important assessment tools and managerial aids.

Huber (1983) further suggested that performance appraisal serves three purposes: evaluation, development, and employee protection, what makes his suggestions distinct from the descriptions of the purpose of performance appraisal by other authors is that Huber emphasized the role of performance appraisal as a tool that helps prevent any misunderstanding between employees and supervisors.

Likewise, Gabris and Ihrke (2000) also suggested three uses of performance appraisal: first, it is a tool to provide periodic and formal feedback to individual employees so that they can understand their performance level compared to the goals and expectations of their employing organization second, it is used to control employee behavior and performance results; and finally, it is used to set a standard to determine employee compensation.

Roberts and Pavlak (1996)and Mani (2002) noted that effective performance appraisals can help employees improve their performance because they can produce specific performance feedback. They suggested that performance appraisal also helps managers identify their training needs. In addition, they noted that if performance appraisals were operated effectively, they would contribute to increasing employee motivation and, by consequence, increasing their productivity. In this perspective, performance appraisal is believed to help both management and employees to work toward the same goal, which eventually contributes to improving organizational performance. 
Daley et al., (2002) also explained performance appraisals from the manager's perspective and suggested that it is a useful decision-making tool for public managers to "make appropriate decisions that rationally contributes to the organizations and individual's effectiveness and well-being". As Fletcher (2001) noted, performance appraisals can play a role for managing both organizational and employee performance as well as for integrating both of these into the organizations' broader goals. Moreover, effective performance appraisals motivate employees to strive for performance improvement by linking appraisals to performance-contingent rewards.

Mani (2002) noted that when organizations costly litigation when they are unable to support decisions to terminate or lay off employees. In the absence of a valid system for assessing the performance of all employees, managers risk suboptimum promotion decisions they may promote one employee and increase his or her pay when another employee's performance would be superior and give a higher return on the salary investment.

In sum, PA in theory contributes to advancing supervisor-employee understanding, validating promotion and hiring procedures and reinforcing organizational values by supporting an organization's culture (Murphy and Cleveland ,1991). It is clear from the preceding discussion that in theory PA is a pivotal human resource management tool that can benefit all the involved parties: organization, supervisor, and individual employee. Given these expected benefits, many government organizations are striving to develop an effective performance appraisal (Murphy and Cleveland, 1991, Daley, 1992; Roberts et al.,, 1996; Roberts, 2003).

\section{Research Methodology}

\subsection{Population and Sample}

A questionnaire was developed to investigate the role of leader-member exchange and impression management in employee performance in five star hotels located in Cairo). As indicated by the Egyptian Hotel Association (2016) there are 33 five star hotels in Cairo. A Convenience sample of 20 five star hotels located in Cairo was chosen for investigation. A list of these hotels can be found in appendix A. A total of 362 forms were received representing a response rate of $86.2 \%$.

Questionnaire form was divided into four parts. The first part was about the demographics of the respondents and other work-related information. The second part to measure the level of employee's impression management behaviors It included 22 statements divided into five subsection which are selfpromotion, ingratiation, exemplification, intimidation and supplication based on Bolino and Turnley (1999) scale which based on Jones and Pittman (1982) scale.

A five point scale was used ranging from (1) never behave this way to (5) often behave this way. Kacmar et al., (2007) in their work on looking for further approval on the Bolino and Turnley (1999) IM scale's, they attested that there is an empirical evidence for its validity, in addition, all five subscales produced acceptable internal consistency exceeded 0.75 . 
They included, the development of the items version of the impression management scale, employable to examine these five tactics, and marked a very important step in the process of assembling a reliable and valid tool to study impression management behaviors in different organizational settings.

The third part investigated leader member exchange. Leader-Member Exchange was measured by the multidimensional LMX scale (LMX-MDM) created by Liden and Maslyn (1998). This measure comprises of 12 items concerned with the four fundamental dimensions of LMX namely;affect, loyalty, contribution, and professional respect. Each dimension contained three items, Employees responded to these items on a five-point Likert scale. Finally, the last part inquires about the employees performance).Employees Performance were measured by a scale created by Podsakoff and MacKenzie (1994). Employees responded to these items on a five-point Likert scale

\section{Results and Discussion}

\subsection{Reliability analysis}

The reliability of the scales was tested using Cronbach' alpha coefficient to measure internal reliability; its value ranging from 0 to 1 and higher values indicate greater reliability. Cronbach' alpha for this study was 0.7 as indicated in table (1).

Table (1): (Reliability coefficient of the questionnaire items)

\begin{tabular}{|c|l|c|c|}
\hline Serial & \multicolumn{1}{|c|}{ Scale } & No. of items & Alpha \\
\hline I & Employees Performance & 10 & .709 \\
\hline II & Leader Member Exchange & 12 & .771 \\
\hline III & Impression Management Behavior/s & 22 & .777 \\
\hline
\end{tabular}

\subsection{Respondents profile and work related information}

\begin{tabular}{|c|c|c|c|}
\hline $\begin{array}{c}\text { Demographic and other Work- related } \\
\text { Information }\end{array}$ & Classes & Freq. & $\%$ \\
\hline \multirow{2}{*}{ 1. Gender } & Male & 262 & 74.5 \\
\hline & Female & 100 & 25.5 \\
\hline \multirow[t]{3}{*}{ 2. Age } & Less than 30 years & 199 & 65.5 \\
\hline & $30: 40$ years & 131 & 32 \\
\hline & More than 40 years & 32 & 2.5 \\
\hline \multirow[t]{2}{*}{ 3. Marital status } & Single & 112 & 29.8 \\
\hline & Married & 250 & 70.2 \\
\hline \multirow[t]{3}{*}{ 4. Educational level } & Technical & 103 & 32 \\
\hline & Bachelor & 228 & 66 \\
\hline & Master/PhD & 31 & 2 \\
\hline \multirow[t]{2}{*}{ 5. Work area } & Front of the house & 112 & 21.9 \\
\hline & Back of the house & 250 & 78.1 \\
\hline \multirow{3}{*}{ 7. Years of experience } & Less than 5 year & 244 & 75.8 \\
\hline & Between 5 to 10 year & 73 & 22.2 \\
\hline & More than 10 year & 45 & 2 \\
\hline \multirow[t]{3}{*}{ 8. Years of current job } & Less than 5 year & 251 & 74.5 \\
\hline & Between 5 to 10 year & 69 & 22.2 \\
\hline & More than 10 year & 42 & 3.3 \\
\hline
\end{tabular}


Table( 2 ) demonstrate that out of the 362 respondents, the majority of 262(74.5\%) were male, 100 (25.4) were female, 199(65.9\%) belong to less than 30 years old, $131(34.1 \%)$ belong to from30:40 years old group. Also, 250 $(70.2 \%)$ of the respondents are married, and $112(29.8 \%)$ are single. The data also indicate that the majority of $228(66.2 \%)$ have a bachelor degree and 103 $(32.1 \%)$ graduated from technical schools. Also, $112(21.9 \%)$ of the respondents are working in the front-of-the-house area, and $250(78.1 \%)$ are working in the back-of-the-house area.

Also, $220(72.8 \%)$ of the respondents are less than 5 year experience, 244 (4.96\%) are more than 10 year experience and 45 (22.2) are between 5 to 10 year experience. The data also point out that the majority of $251(74.5 \%)$ belong to less than 5 year in current job, 69 (22.2) between 5 to 10 year, 42 $(3.3 \%)$ belong to more than 10 years in current job.

\subsection{LMX and employees performance.}

Table ( 3 ): Relationship between LMX and employees performance

\begin{tabular}{|l|l|l|c|c|c|c|c|c|}
\hline Variable & \multicolumn{1}{|c|}{ Model } & Coefficients & $\mathrm{t}$ & Sig. & Beta & $\mathrm{R} 2$ & $\mathrm{~F}$ & Sig. \\
\hline LMX & Constant & 2.970 & 6.404 & .000 & .367 & .134 & 9.000 & .004 \\
\cline { 2 - 9 } & Performance & .361 & 3.000 & .004 & & & & \\
& & & & & & & & \\
\hline
\end{tabular}

A simple regression was conducted to investigate the effect of LMX on employee's performance from managers perspectives. The predicted variable was the performance whereas the criterion variable was the managers' independent variables (LMX). The results indicated that $13.4 \%$ of variance in performance can be influenced by managers' LMX $(\mathrm{R} 2=.134)$. The ANOVA result indicated that it was a good regression model $(\mathrm{p}=.004)$. Based on the coefficient results, the managers' LMX was a good predictor to predict their performance $(\mathrm{p}=.004)$. The regression model is: \{managers' performance $=$ $2.970+(.361 \mathrm{X}$ LMX) $\}$.

The findings reveal that LMX has direct positive influences on employee performance as shown in table (3).so that the hypothesis of There is no significant relationship between leader member exchange and employees performance is rejected 
The results indicated that $13.4 \%$ of variance in performance can be influenced by managers LMX as high quality exchanges make supervisors trust their subordinates and let them share in different decisions affecting the work unit. This sharing gives employees additional experience and strengthens their performance which in turn leads to high performance. According to Wayne et al. (2002) in-groups are asked to participate in many nontrivial decisions which in turn will foster their performance, and lead supervisors to give them high performance ratings.

As well, according to Erdogan (2002) performance occurs within the context of an ongoing relationship between the leader and member. This result is consistent with our study and most results of previous studies exploring this relationship (Bauer et al., 2006; Duarte et al., 1994;Gerstner \& Day, 1997; Liden et al., 1998 .

This result is also consistent with the study of (Graen et al., 1982, Green et al., 1996 ) which approve that employees with high LMX are able to have a more positive attitude at work, and thus improved performance. the result is compatible with the result of (Li et al., 2012, Testa, 2009, Wang and Wong, 2011) which confirm that high LMX employees in the hospitality industry tend to have more motivation and creative ideas, are associated with greater customer satisfaction and work performance.

\section{Impression management and employees performance}

Table(4):The relationship between impression management and employees performance

\begin{tabular}{|c|c|c|c|c|c|c|c|c|}
\hline Variable & Model & Coefficients & $\mathbf{T}$ & Sig. & Beta & R2 & $\mathbf{F}$ & Sig. \\
\hline \multirow[t]{2}{*}{ Self-promotion } & Constant & 4.714 & 41.813 & .000 & \multirow[t]{2}{*}{-.331} & \multirow[t]{2}{*}{.109} & \multirow[t]{2}{*}{36.855} & \multirow[t]{2}{*}{.000} \\
\hline & Performance & -.178 & -6.071 & .000 & & & & \\
\hline \multirow[t]{2}{*}{ Ingratiation } & Constant & 4.244 & 46.681 & .000 & \multirow[t]{2}{*}{-.126} & \multirow[t]{2}{*}{.016} & \multirow[t]{2}{*}{4.856} & \multirow[t]{2}{*}{.028} \\
\hline & Performance & -.066 & -2.204 & .028 & & & & \\
\hline \multirow[t]{2}{*}{ Exemplification } & Constant & 4.233 & 39.381 & .000 & \multirow[t]{2}{*}{-.099} & \multirow[t]{2}{*}{.010} & \multirow[t]{2}{*}{2.957} & \multirow[t]{2}{*}{.087} \\
\hline & Performance & -.076 & -1.720 & .087 & & & & \\
\hline \multirow[t]{2}{*}{ Intimidation } & Constant & 4.177 & 58.129 & .000 & \multirow[t]{2}{*}{-.108} & \multirow[t]{2}{*}{.012} & \multirow[t]{2}{*}{3.559} & \multirow[t]{2}{*}{.060} \\
\hline & Performance & -.062 & -1.887 & .060 & & & & \\
\hline \multirow[t]{2}{*}{ Supplication } & Constant & 4.116 & 61.824 & .000 & \multirow[t]{2}{*}{-.066} & \multirow[t]{2}{*}{.004} & \multirow[t]{2}{*}{1.293} & \multirow[t]{2}{*}{.256} \\
\hline & Performance & -.030 & -1.137 & .256 & & & & \\
\hline \multirow{2}{*}{$\begin{array}{ll}\text { Total } & \text { IM } \\
\text { behaviors } & \end{array}$} & Constant & 4.713 & 32.481 & .000 & \multirow[t]{2}{*}{-.259} & \multirow[t]{2}{*}{.067 } & \multirow[t]{2}{*}{21.516} & \multirow[t]{2}{*}{.000} \\
\hline & Performance & $\begin{array}{l}.259 \\
-.25\end{array}$ & -4.639 & .000 & & & & \\
\hline
\end{tabular}


Table ( 4 ) indicates that there is no significant correlation exist between impression management and employees performance. Performance evaluation is an impression management event (Villenova \& Bernardin, 1989). so that this hypothesis is accepted.

A possible explanation to the negative relationship is that impression management behaviors in general are not acceptable in the hotel culture. When managers realize that their subordinates' use of such behaviors they give them negative performance.

This result is agree with the study of Rhodewalt et al., (1995) which approve that impression management was found in more than one study to be negatively related to employees' performance. In Bolino \&Turnley (2001) they found that impression management tactics negatively impacted women's performance evaluations. Also, another study by Bolino \&Turnley (2003) found that the use of intimidation tactics of IM was unrelated to performance evaluations among female employees.

These results disagree with the results of other studies that concluded that impression management behaviors affect employee performance positively, either directly or indirectly. For example, Wayne and Kacmar (1991) found that assertive IM tactics (self-promotion, ingratiation, intimidation, supplication) influence employee's performance positively. Gundersen et al. (1996) also found that IM tactics influence employees' performance. Wayne and Ferris (1990) in their study found that impression management, by improving superior-subordinate exchange, improves employees' performance. Another studies conducted by (Gordon, 1996; Kacmar\& Carlson, 1999) found that there is a positive relationship between employees use of impression management tactics and employees performance. According to Watt's field study (1993) approve that bank employees who used impression management tactics not only received higher employees performance, but also were considered more competent and were thought to possess more leadership ability.

Another possible explanation is that when employees become so busy with consciously practicing impression management behaviors to influence the target audience (supervisors), they spend time and effort to do for example extra assignments to their supervisors, and become delinquent in their basic tasks and duties, which hinders their actual performance, and thus receive lower ratings than those who do not use these behaviors.

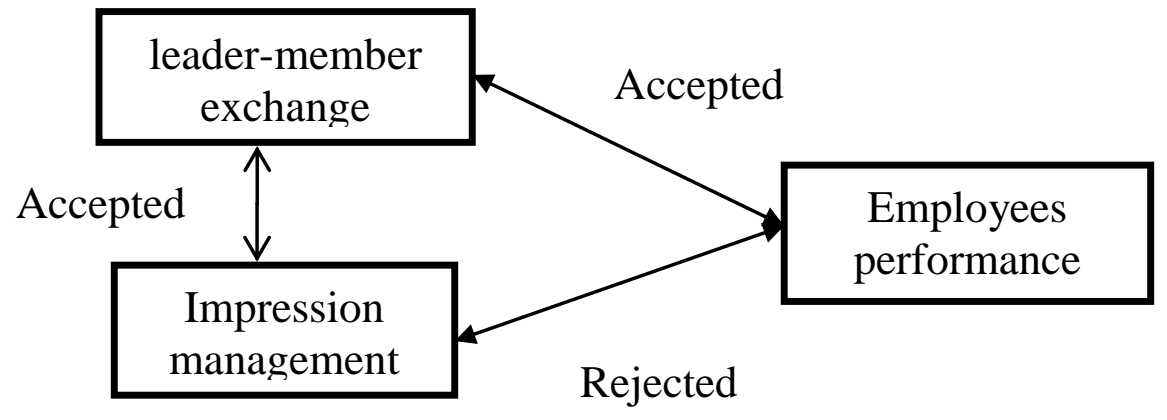

Figure (1): Result of study hypotheses 


\section{5 . Conclusion}

The objective of the current study were to identify the role of leader member exchange and impression management on employee performance in hotels.

Hotels can encourage leaders to build high-quality relationships with their members,(Liao et al., 2010). This is because the goal of the hospitality industry is to meet the expectations of customers, and high quality services are more likely to be delivered if employees have highly reciprocal relationships with their leaders (Chang et al., 2011, Wong and Ladkin, 2008). Most importantly, the positive relationships that exist between supervisors and their subordinates can encourage employees to perform their tasks more creatively.

More specifically, the accumulation of LMX, impression management can together lead to high employee's performance. Accordingly, managers or department leaders in hotels should provide more opportunities for the relationship between leaders and members. Meanwhile, managers can also provide training programs for supervisors and employees to enhance their reciprocal relationships, and establish reward mechanisms to increase employee's performance.

The study findings revealed that there is a significant relationship between leader member exchange and employee performance. The study revealed that $13.4 \%$ of variance in employee's performance can be influenced by LMX. As high leader member exchanges make leaders trust their members and let them share in different decisions affecting the work unit which in turn leads to high employees performance.

Five impression management behaviors were chosen in the study to investigate their effects on employee's performance namely; self-promotion, ingratiation, exemplification, intimidation, and supplication. The study findings also revealed that there is no significant relationship between impression management and employees performance as when managers realize that their employee's use of such behaviors they give them negative performance and impression management behaviors in general are not acceptable in the hotel culture. 


\section{Recommendations}

Based on the findings of this study, a number of recommendations can be suggested as follows:

1- Management needs to pay attention to the quality of LMX, as today's employees look for mutual trust. Recognizing employees potential through quality of exchange relationships might be useful to strengthen the level of commitment and decrease turnover intentions in the organization, in addition to reducing the number of filed grievances at work, creating a better working environment.

2- Studying employee motives and needs to provide a better understanding of resulting employees' impression management behaviors and leader member exchange relationships. Employee needs can be identified through surveys, questionnaires, interviews. Thus, hotels can develop an incentive system to satisfy these needs and enhance performance, in addition to encouraging employee creativity and innovation.

3- Good training programs can be executed to provide the managers and the supervisors with knowledge and skills needed to be aware of at different levels of different impression management behaviors to obtain favorable outcomes (such as job satisfaction, favorable employee's performance, promotion and profitability).

4- Managers in hotels should recognize the importance of LMX in the workplace and try enhancing such relationships between leaders and their members.

5- Management must concern of various impressions management tactics that used in the interviews to ensure a candidatequalifications.

6- Hotels should realize that LMX and IM can be strongly related. As employees enjoy a high-quality exchange, they may use certain types of IM such as (ingratiation and exemplification) to get the benefits and promotion. On the other hand, the successful use of IM tactics may initiate a high-quality exchange between an employee and his supervisor. 


\section{References}

Arkin, R. M. (1981). "Self-presentational styles". Impression management theory and social psychological research. I. J. T. T. (Ed.), New York: Academic Press: 311-333.

Arkin, R. M. and J. A. Sheppard (1990). "Strategic self-presentation: An overview", The psychology of tactical communication. M. J. M. Cody, M. L. Bristol, Multilingual Matters Ltd: 174-193.

Bauer, T. N., Erdogan, B., Liden, R. C., \& Wayne, S. J. (2006). A longitudinal study of the moderating role of extraversion: Leader-member exchange, performance, and turnover during new executive development. Journal of Applied Psychology, 91(2), 298-310.

Baumgardner, A. H. and R. M. Arkin (1987). Coping with the prospect of social disapproval: Strategies and sequelae. Coping with negative life events: Clinical and social psychological perspectives. C. R. S. C. E. Ford. New York, NY, US, Plenum Press:323-346.

Baumgardner, A. H., C. M. Kaufman,(1989). "Regulating affect interpersonally: When low esteem leads to greater enhancement." Journal of personality and social psychology 56(6): 907-921.

Baumeister, R. F., D. M. Tice,(1989). "Self-Presentational Motivations and Personality Differences in Self-Esteem." Journal of Personality 57(2): 547-579.

Blau, P. M. (1964). Exchange and power in social life. New York: John Wiley \& Sons.

Buss, D. M. and L. A. Dedden (1990). "Derogation of competitors." Journal of personality and social psychology 56: 907-921.

Bolino, M.and Turnley, W. (1999). Measuring Impression Management in Organizations: A Scale Development Based on the Jones and Pittman Taxonomy. Organizational Research Methods, 2, 187-206.

Bolino, M. C., \& Turnley, W. H. (2001). Gender and the use of supplication and intimidation in organizations. Paper presented at the Academy of Management Meetings Washington, D.C

Bolino, M. C., \& Turnley, W. H. (2003). More than one way to make an impression: Exploring profiles of impression management. Journal of Management, 29(2), 141-160.

Buss, D. M. and L. A. Dedden (1990). "Derogation of competitors." Journal of personality and social psychology 56: 907-921.

Chang, S., Gong, Y. P. and Shum, C. (2011), "Promoting innovation in hospitality companies through human resource management practices", International Journal of Hospitality Management, Vol.30 No.4, pp. 812-818.

Daley, DM (1992). Performance appraisal in the public sector: Techniques and applications. Westport, CT: Quorum 
Daley, D., Vasu, M. L., \& Weinstein, M. B. (2002). Strategic human resource management: Perceptions among North Carolina county social service professionals. Public Personnel Management 31(3), pp.359-375.

Decotiis, T., \& Petit, A. (1978). The performance appraisal process: A model and some testable propositions. Academy of management review 3(3), pp.635646.

Duarte, N. T., Goodson, J. R., \& Kilch, N. R. (1994). Effects of dyadic quality and duration on performance appraisal. Academy of Management Journal, 37 , 499-521.

Erdogan, B. \& Liden, R. C. (2002). Social Exchanges in the Workplace: A review of recent developments and future research directions in leader-member exchange theory.

Fletcher, C. (2001). Performance appraisal and management: The developing research agenda. Journal of Occupational and organizational Psychology74(4), pp.473-487.

Gabris, G.T. \& Ihrke, D.M. (2000). Improving Employee Acceptance toward Performance Appraisal and Merit Pay Systems: The Role of Leadership Credibility. Review of Public Personnel Administration 20, pp. 41-53.

Gerstner, C. R., \& Day, D. V. (1997). Meta-analytic review of leader member exchange theory: Correlates \&construct issues Journal of Applied Psychology, $82,827-844$.

Gordon, R. A. (1996). Impact of ingratiation on judgments an evaluations: A meta-analytic investigation. Journal of Personality and Social Psychology, 71, 54-70.

Gouldner, A. W. (1960). The norm of reciprocity: A preliminary statement. American Sociological Review, 25, 161-178.

Graen, G. B. (1976). Role-making processes within complex organizations . In M. D. Dunnette (Ed.), Handbook of industrial and organizational psychology. (pp. 1201-1245). Chicago: Rand McNally.

Graen, G. B., Novak, M. A., \& Sommerkamp, P. (1982). The effects of leadermember exchange and job design on productivity and satisfaction: Testing a dual attachment model. Organizational Behavior and Human Performance, 30, 109-131.

Graen, G. B., \& Scandura, T. A. (1987). Toward a psychology of dyadic organizing. Research in Organizational Behavior, 9, 175-208.

Graen, G.B., \& Uhl-Bien, M. (1995). Relationship-based approach to leadership: Development of leader-member exchange (LMX) theory of leadership over 25 years: Applying a multi-level multi-domain perspective. Leadership Quarterly, 6, 219-247. 
Green, S.G. (1996). Development of leader-member exchange: a longitudinal test. Academy of Management Journal , 39, 1538-1567.

Gronn, P. (2002). Distributed leadership as a unit of analysis. Leadership Quarterly, 13, 423-451.

Gundersen, D. E., Tinsley, D. B., \& Terpstra, D. E. (1996). Empirical assessment of impression management biases: The potential for performance appraisal error. Journal of Social Behavior \& Personality, 11 , 57-76.

Huber, V. L. (1983). An analysis of performance appraisal practices in the public sector: A review and recommendations. Public Personnel Management 12(3), pp.258-267.International Journal of Conflict Management, 19(2), 92111.

Jones, E. E., \& Pittman, T. S. (1982). Toward a general theory of strategic selfpresentation. In J. Suls (Ed.). Psychological perspectives on the self. (pp. 231262). Hillsdale, NJ: Lawrence Erlbaum.

Kacmar, K. M., \& Carlson, D. S. (1999). Effectiveness of impression

management tactics across human resource situations. Journal of Applied Social Psychology, 29, 1293-1315.

Kacmar, K., Harris K. and Nagy, B. (2007). "Further validation of the Bolino and Turnley impression management scale," Journal of Behavioral and Applied Management, pp. 16-32.

Katz, D., \& Kahn, R. L. (1966). The social psychology of organizations . (2nd ed.). New York: Wiley.

Kumar, K. and Beyerlein, M. (1991). Construction and Validation of the Measure of Ingratiatory Behaviors in Organizational Settings (MIBOS). Journal of Applied Psychology, 76, 619-627.

Lacho, K. J., Stearns, G. K., \& Whelan, R. K. (1991). Performance appraisal in local government: A current update. Public Productivity; Management Review, 281-296.

Leary, M. R. and R. M. Kowalski (1995). Social anxiety. New York, Guilford Press.

Leary, M. R. (1996). Self presentation: Impression management and interpersonal behaviour.Brown \& Benchmark Publishers.

Li, X. B., Sanders, K. and Frenkel, S. (2012), "How leader-member exchange, work engagement and HRM consistency explain Chinese luxury hotel employees' job performance", International Journal of Hospitality Management, Vol.31 No.4, pp. 1059-1066.

Liao, H., Liu, D. and Loi, R. (2010), "Looking at both sides of the social exchange coin: A social cognitive perspective on the joint effects of relationship quality and differentiation on creativity", Academy of Management Journal, Vol.53 No.5, pp. 1090-1109. 
Liden, R. C., \& Maslyn, J. M. (1998). Multidimensionality of leader member exchange: an empirical assessment through scale development. Journal of Management , 24(1), 43-72.

Longenecker, C. O., \& Nykodym, N.(1996). Public sector performance appraisal effectiveness: A case study. Public Personnel Management, 25(2), 151-164.

Mani, B. G. (2002). Performance appraisal systems, productivity, and motivation: A case study. Public Personnel Management, 31(2), 141-159.

McGregor, D. (1972). Uneasy look at Performance appraisal. Harvard Business Review 50(5), pp.133.

Mohrman Jr, A. M., Resnick-West, S. M., Lawler III, E. E., Driver, M. J., Von Glinow, M. A., \& Prince, J. B. (1989). Designing performance appraisal systems: Aligning appraisals and organizational realities. Jossey-Bass.

Murphy, K.R. \& Cleveland, J.N. (1991). Performance appraisal: An Organizational Perspective. Boston: Allyn and Bacon 1995). Understanding Performance Appraisal: Social, Organizational, and Goal-Based Perspectives. Thousand Oaks, CA: Sage Publications

Oh, S. S., \& Lewis, G. B. (2009). Can performance appraisal systems inspire intrinsically motivated employees?. Review of Public Personnel Administration 29(2), pp.158-167.

Podsakoff, P. M. \& MacKenzie, S. B. (1994). Organizational citizenship behavior and sales unit effectiveness. Journal of Marketing Research, 31, 351363.

Rhodewalt, F., Sanbonmatsu, D. M., Tschanz, B., Feick, D. I., \& Waller,A. (1995). Self-handicapping trade-offs: The effect of claimed self-handicaps on observers' performance evaluation and feedback.Personality and Psychological Bulletin, 21 , 1042- 1050.

Roberts, Gary E. \& Pavlak, T. (1996). Municipal Government Personnel Professionals and Performance Appraisal: Is There Consensus on the Characteristics of an Effective Appraisal System?. Public Personnel Management, 25(3), pp. 379-408.

Roberts, G. E. (2003). Employee performance appraisal system participation: A technique that works. Public Personnel Management 32(1), pp.89-98.

Roth, D. L., R. N. Harris(1988). "An Individual Differences Measure of Attributive and Repudiative Tactics of Favorable Self-Presentation." Journal of Social and Clinical Psychology 6(2): 159-170.

Schlenker, B. R. (1980). Impression management: The self-concept, social identity, and interpersonal relations. 
Schlenker, B. R., \& Leary, M. R. (1982). Audiences' reactions to self enhancing, selfdenigrating, and accurate self-presentations. Journal of Experimental Social Psychology,18, 89-104.

Schlenker, B. R. and M. R. Leary (1985). "Social anxiety and communication about the self."Journal of Language and Social Psychology 4(3-4): 171-192.

Schutz, A. and B. M. DePaulo (1996). "Self-Esteem and Evaluative Reactions: Letting People Speak for Themselves." Journal of research in personality 30(2): 137-156.

Schutz, A., K. Richter, et al. (1997). "Self-Presentation in Client-Therapist Interaction: A Single Case Study." Journal of Social and Clinical Psychology 16(4): 440-462.

Schutz, A. (1998). "Audience Perceptions of Politicians' Self-Presentational BehaviorsConcerning Their Own Abilities." The Journal of social psychology 138(2): 173-188.

Shalley, C. E., Zhou, J. and Oldham, G. R. (2004), "The effects of personal and contextual characteristics on creativity: Where should we go from here?"

Journal of Management, Vol.30 No.6, pp. 933-958.

Tedeschi, J. T. (1985). Social power, self-presentation, and the self. The self and social life. S. (Ed.), New York, McGraw-Hill: 293-322.

Testa, M. R. (2009), "National culture, leadership and citizenship: Implications for cross-cultural management", International Journal of Hospitality Management, Vol.28 No.1, pp. 78-85.

Tierney, P. and Farmer, S. M. (1999), "Creative self-efficacy: Its potential antecedents and relationship to creative performance", Academy of Management Journal, Vol.45 No.6, pp. 1137-1148.

Truckenbrodt, Y. B. (2000). "The relationship between Leader-member exchange and commitment and organizational citizenship behavior. Acquisition Review Quarterly, 7, 233-244.

Villanova, P., \& Berdnardin, H. J. (1989). Impression management in the context of performance appraisal . In Giacalone, R. A.,Rosenfeld, P. (Eds). Impression management in the organization. (pp. 299-313). Hillsdale, NJ: LawrenceErlbaum.

Wang, H.(2011). Leader-member exchange as a mediator of the relationship between transformational leadership and followers' performance and organizational citizenship behavior. Academy of Management Journal , 48, 420-32.

Watt, J. D. (1993). The impact of the frequency of ingratiation on the performance evaluation of bank personnel. Journal of Psychology, 127, 171182. 
Wayne, S. J. \& Ferris, G. R. (1990). Influence tactics, affect, and exchange quality in supervisorsubordinate interactions: A laboratory experiment and field study. Journal of Applied Psychology, 75(5): 487-499.

Wayne, S. J., \& Kacmar, M. K. (1991). The effects of impression management on the performance appraisal process. Organizational Behavior and Human Decision Processes, 48,70-88.

Wayne, S. J., Shore, L. M., Bommer, W. H., and Tetrick, L. E. (2002). The Role of Fair Treatment and Rewards in of Organizational Support and LeaderMember Exchange. Journal of Applied Psychology, 87, 590-598.

Wong, S. and Ladkin, A. (2008), "Exploring the relationship between employee creativity and job-related motivators in the Hong Kong hotel industry", International Journal of Hospitality Management, Vol.27 No.3, pp. 426-437

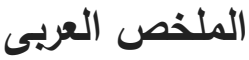

دور التبادل بين القائد والمروئوس وإدارة الانطباع فى أداء العاملين بالفنادق

تهدف هذه الدراسة إلى معرفة دور التبادل بين القائد والمرؤوس و إدارة الانطباع في أداء العاملين

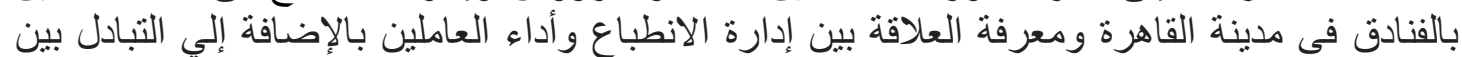

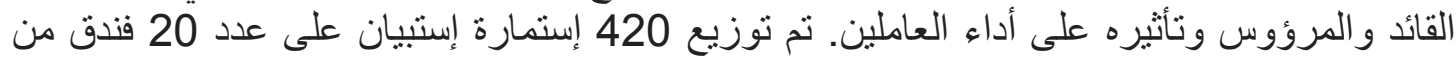

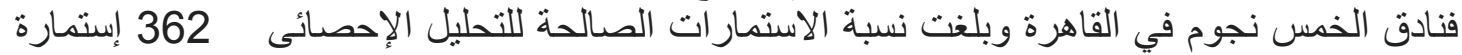

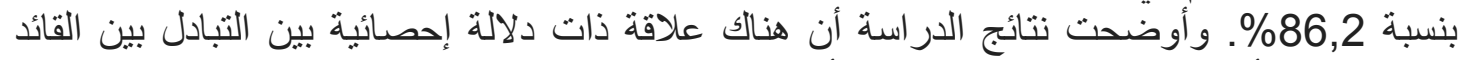

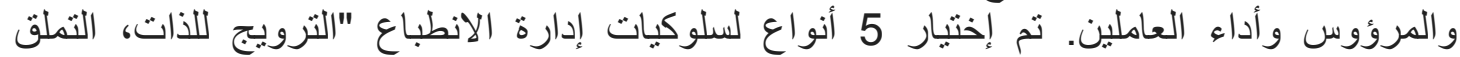

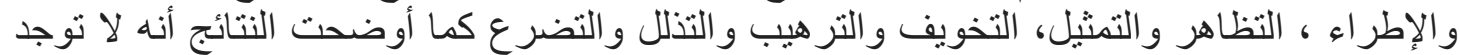

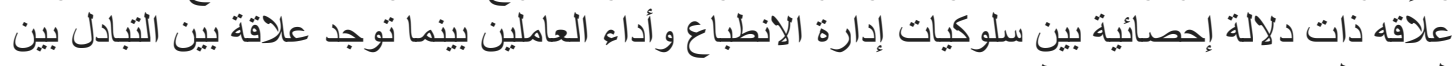

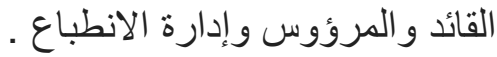

